in 1978 and 1979, when I often went to Fort Qu'Appelle to help him checking his MS of Birds of the Qu'Appelle (18571979) (SNHS Special Publication No.13), I inquired about the absence of the sighting in his account of the occurrences of Lewis' Woodpecker. He did not remember the incident nor, when he searched his records, could he find a reference. At home I looked for the account I recalled writing but to no avail - it had disappeared. Birds of the Qu'Appelle (1857-1979) was published without it.
Recently I discovered the account I had written on 17 June 1972. The details appear above. I offer this as an amendment to HOUSTON, C. STUART and MARY I. HOUSTON. Additions to Callin's Birds of the Qu'Appelle. Blue Jay $44: 70-84$.

${ }^{1}$ BELCHER, Margaret. 1980. Birds of Regina. Spec. Pub. No.12, Sask. Nat. Hist. Soc. 151 pp.

\title{
TWO RUFFED GROUSE ENCOUNTERS
}

JIM A. WEDGWOOD, 610 Leslie Avenue, Saskatoon, Saskatchewan. S7H 2 Z2

\section{Another "Crazy-flight"}

In the morning on 4 September 1988, Ken Giesbrecht noticed from his cottage window at Big Shell Lake a stray cat stalking a covey of 10 Ruffed Grouse. Some birds were on the ground, others were in trees, all watching the cat. Then in ones, twos and threes, the grouse flushed, rocketing through the poplars toward the adjacent lot where, except for three birds, they veered around and over a shed. The three, however, in quick succession crashed fatally into a window on the shed.

Ken concluded the birds were immatures. Upon dressing the carcasses, he found the skin over the keel split readily, whereas he finds it tough on older grouse. He remarked that both shanks of the wishbone (furcula) on each bird were broken.

The small $91 \times 45 \mathrm{~cm}(36 \times 18$ in.) window struck by the birds was the middle one of a set of three placed high in the wall under a protruding roof. With no windows in the opposite wall of the unlit shed, a bird should not have been miscued by a view through the building; there might have been, however, a reflected image of the trees behind them.

Ken believed the two followers may have been acting as did two pilots in the recent tragedy of a three-member aerobatics team. There the leader misjudged, flew into the ground, and the other two followed him. Opinion was that the following pilots had concentrated on keeping station to the exclusion of all else.

The phenomenon of Ruffed Grouse occasionally flying wildly about and often hitting objects, including windows, has been termed "crazy-flight."2 Implying knowledge of the trait was the old-timer who years ago cautioned me to board up our cottage windows in the fall, "to stop the stupid grouse from breaking the glass." In articles in Blue Jay, Victor Friesen reviewed the literature on the subject and noted that 16 theories had been advanced to explain crazy-flights. ${ }^{23}$ Regardless of cause, and recognizing that others of the covey had already dodged the shed, crazy-flight behaviour would seem to fit the actions of the lead bird in the Shell Lake instance. 


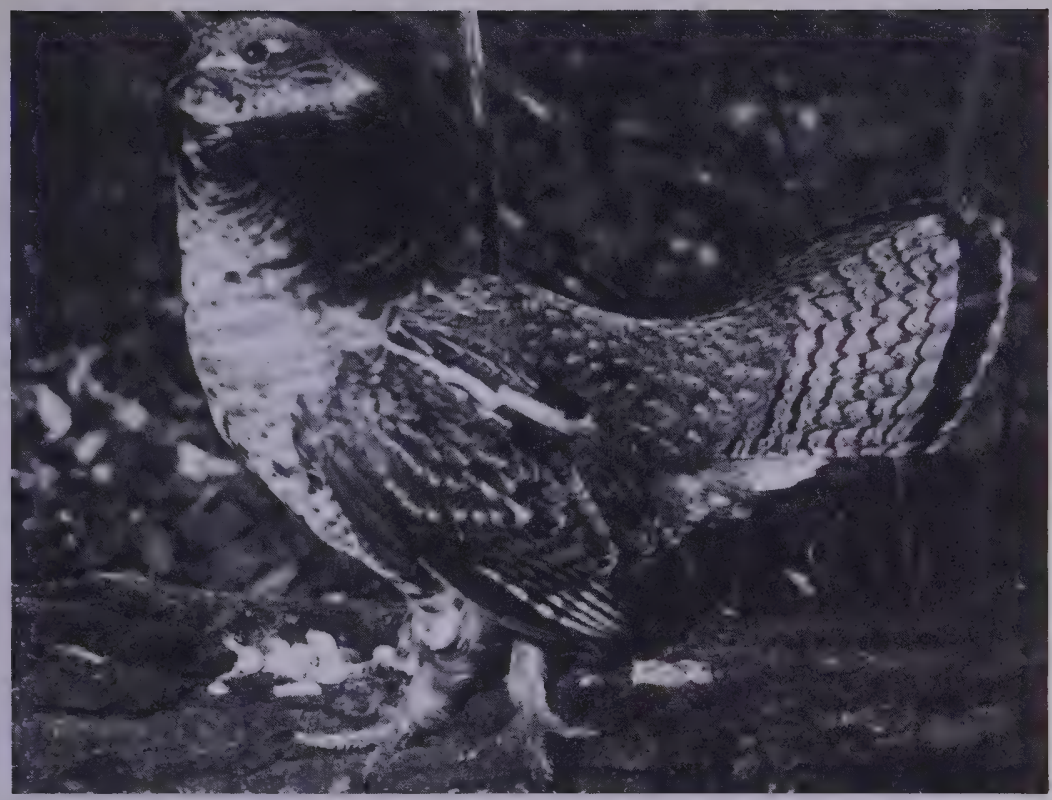

The following birds' actions, or lack of them, are puzzling. Were they driven by a follow-the-leader urge or by a crazyflight mechanism? That all three Shell lake birds appeared to have suffered the same terminal damage suggests that neither following bird was slowing down or veering at impact.

Of 11 crashes in the Rosthern district recounted by Friesen and nine in Manitoba remarked on by Dennis Fast, a total of 20 incidents, only once was more than one bird stated to be involved. ${ }^{1234}$ In that case the lead grouse of a covey veered off, but one of the following birds did not, crashing into a house.

Interesting as a casual discussion may be, the salient feature of Giesbrecht's observation was the number of crashes involved, three, resulting in a 30 per cent loss in the covey due to one event.

\section{Unusual Location for Ruffed Grouse}

While on a Loggerhead Shrike survey in the Dinsmore district on 7 July 1987, Jim Slimmon and I saw a Swainson's Hawk diving repeatedly on a grousesized bird. We were surprised to see through our binoculars a Ruffed Grouse attempting to fend the hawk away from two chicks. Jim ran out into the field and at least temporarily scared off the hawk.

The field was $12.8 \mathrm{~km}$ south and 9.6 $\mathrm{km}$ east of Forgan in an area devoid of aspen bluffs. The only trees in sight were planted farmyard shelterbelts, although there seemed to be more of these in the Dinsmore district than elsewhere on the plains in this west-central part of the province. Salt, in Birds of Alberta, notes that, although not found on the open prairie, the species occurs along wooded valleys that cut through the prairies. ${ }^{5}$ The nearest wooded coulee 
was about $16 \mathrm{~km}$ to the south in the Missouri Coteau; the closest wooded valley was the Anerley Lakes chain $29 \mathrm{~km}$ to the northeast. The presence of a Ruffed Grouse in this locale was remarkable.

Contributing to the oddity of the occurrence was the site itself: the grouse was $50 \mathrm{~m}$ into clean summerfallow about $200 \mathrm{~m}$ east of a shelterbelt arid $25 \mathrm{~m}$ west of a small, shallow creek bed. The dry creek bed had tall grasses, weeds, scattered buckbrush and small willow bushes, but no trees.

We surmised that the grouse was caught moving her brood between shelterbelt and creek. But why she was there, why she was making the move and why she did not travel through the roadside grasses were unknowns. The observation was unusual.
I am grateful to Ken Giesbrecht and Jim Slimmon for comments on their respective interests in this article.

${ }^{\top}$ FAST,D. 1979. Grouse flying crazy and dancing high. Blue Jay 37:219-220.

${ }^{2}$ FRIESEN, V.C. 1971. The crazy flight phenomenon of the Ruffed Grouse. Blue Jay 29:121-124.

3 1978. Further observations of the Ruffed Grouse's "crazy-flight." Blue Jay 36:192-199.

4 1980. Crazy grouse comment. Blue Jay 38:135-136.

${ }^{5}$ SALT, W.R. and J.R. SALT. 1976. The birds of Alberta. Hurtig Publishers, Edmonton. 498 pp.

\title{
BRIEF OBSERVATIONS OF PEREGRINE AND PRAIRIE FALCON BEHAVIOUR
}

\author{
RUDOLF F. KOES, 135 Rossmere Crescent, Winnipeg, Manitoba. R2K 0G1
}

Thinking of large falcons almost invariably conjures up images of power and agility. The popular literature abounds with tales of Peregrine or Prairie falcons seen pursuing prey, if not with the speed of light, then at least faster than a speeding bullet. Sometimes, however, falcons find themselves in more pedestrian situations, as described here.

Peregrine Falcons are the only large falcons regularly observed in Winnipeg. They are most often seen migrating through the city in early May and again in late September. On 25 September 1986, a rainy and windy day, one Peregrine, likely a male, had made a few low, sweeping passes over Fraser's Grove Park in Winnipeg. As it came over once more, in a wide circle on outspread wings, a large moth was carried in its direction by the strong south wind. Their paths closed. The Peregrine tilted slightly to alter its course and, while on its side, attempted to grasp the insect in its talons. The moth was momentarily lost from sight, but then it reappeared, fluttering along again in the wind. The falcon did not try again; it merely continued its barely interrupted circling flight.

I watched the incident through $7 \times 42$ Leitz Trinovid binoculars at a distance of $30-40 \mathrm{~m}$. Although I am not familiar enough with moths to identify them to species at that distance (who is?), the insect was perhaps $2.5 \mathrm{~cm}$ long, with a wingspan of 4 to $5 \mathrm{~cm}$, and it appeared brownish. 